\title{
TINGKAT KEKERASAN DAN DAYA TERIMA BISKUIT DARI CAMPURAN TEPUNG JAGUNG DAN TEPUNG TERIGU DENGAN VOLUME AIR YANG PROPORSIONAL
}

\author{
Miftakhul Istinganah ${ }^{1}$, Rusdin Rauf ${ }^{2}$, Endang Nur Widyaningsih ${ }^{3}$ \\ ${ }^{1}$ Rumah Sakit Mediros Jl. Perintis Kemerdekaan Kav. 149, Jakarta Timur 13260. \\ Email: ${ }^{1}$ syanallamifta@gmail.com \\ ${ }^{2,3}$ Program Studi Ilmu Gizi Fakultas Ilmu Kesehatan Universitas Muhammadiyah \\ Surakarta. Jl. A. Yani, Pabelan, Kartasura, Surakarta. Email: ${ }^{2}$ rusdin.rauf@ums.ac.id, \\ 3 endang.widiyaningsih@ums.ac.id
}

\begin{abstract}
ABSTRAK
Penggunaan tepung jagung sebagai bahan pensubstitusi tepung terigu dapat menurunkan daya terima biskuit. Salah satu penyebabnya adalah penggunaan air dengan volume air yang tidak tepat. Penelitian ini bertujuan untuk mengukur tingkat kekerasan dan daya terima biskuit dari campuran tepung jagung dan tepung terigu dengan volume air yang proporsional. Penelitian ini menggunakan rancangan acak lengkap dengan 4 perlakuan dan 3 kali ulangan, yaitu biskuit dengan campuran tepung jagung dan tepung terigu masing-masing 40:60, 60:40, 80:20, dan 100:0. Penelitian ini dilakukan dengan mengukur daya serap air dari perlakuan campuran tepung jagung dan tepung terigu. Daya serap air dijadikan sebagai acuan volume air dalam pembuatan biskuit dari setiap perlakuan. Selanjutnya diuji kekerasan dan daya terima biskuit dari campuran tepung jagung dan tepung terigu. Hasil penelitian uji kekerasan menunjukkan bahwa terdapat pengaruh biskuit dengan campuran tepung jagung dan tepung terigu. Biskuit dengan campuran tepung jagung dan tepung terigu 40:60 memiliki tingkat kekerasan yang paling tinggi yaitu 3757,00 g. Hasil uji daya terima biskuit menunjukkan bahwa terdapat pengaruh campuran tepung jagung dan tepung terigu terhadap aroma, rasa dan keseluruhan. Namun tidak ada pengaruh terhadap warna dan tekstur biskuit. Secara keseluruhan, perlakuan yang paling disukai adalah campuran tepung jagung dan tepung terigu 80:20.
\end{abstract}

Kata kunci : Biskuit, daya terima, kekerasan, tepung jagung.

\begin{abstract}
The use of corn flour as a substituent ingredient can lower the acceptability of biscuits.One reason is the inappropriate volume of water. The purpose of the research was to determine the hardness and acceptance levels of biscuits from corn flour and wheat flour mixtures, with a proportional volume of water. The randomized completely design was used in the research, with 4 treatments of corn flour and wheat flour ratios, were 40:60, 60:40, 80:20 and 100:0. The research was conducted by measuring the absorption of water from the treatments of flour mixtures. The water absorption was used as a
\end{abstract}


reference to determine the volume of water in the manufacture of biscuits. Then, the hardness and acceptance levels of biscuits were tested. The result showed that the hardness of biscuits was affected by the ratio of corn flour and wheat flour. Biscuits from the treatment of 40:60 revealed the highest hardness level was $3757.00 \mathrm{~g}$. The acceptance test indicated the effect of corn flour and wheat flour ratios to aroma, taste, and overall of biscuits. There was no effect, however, on the color and texture of biscuits. The highest acceptance level for overall was indicated by biscuit from corn flour and wheat flour of 80:20.

Keywords: Biscuits, acceptance, hardness, corn flour.

\section{PENDAHULUAN}

Konsumsi tepung terigu di Indonesia semakin meningkat setiap tahun. Berdasarkan data pada tahun 2011, 2012, dan 2013 impor gandum di Indonesia selalu mengalami peningkatan yaitu sebanyak 6,2 juta ton, 6,7 juta ton dan 7,04 juta ton (APTINDO, 2014). Peningkatan konsumsi tepung terigu dapat berpengaruh terhadap ketahanan pangan, selain itu adanya kandungan gluten 9,61\% (USDA, 2013) dan indeks glikemik yang tinggi yaitu 55-59 (Brand-Miller, 2008)pada tepung terigu juga dapat memberikan efek negatif pada kesehatan, sehingga perlu seggera diatasi.

Salah satu upaya yang dapat dilakukan untuk mengatasi ketergantungan terhadap tepung terigu yaitu dengan cara melakukan sebuah solusi alternatif dengan pembuatan tepung berbasis pangan lokal yaitu jagung.Menurut Suarni dkk (2009) tepung jagung memberikan banyak manfaat, antara lain adanya kandungan betakaroten (provitamin A) yang dapat memberi perlindungan terhadap kebutaan yang disebabkan oleh katarak dengan menjadi filter terhadap sinar UV. Jagung juga mempunyai indeks glikemik yang rendah yaitu antara 28,66 - 41,37 (Richana, 2012), sehingga cocok untuk dikonsumsi oleh penderita diabetes mellitus. Tepung jagung memiliki kadar protein yang hampir sama dengan kandungan protein dalam tepung terigu yaitu 9,2 gram (Nuraini, 2013), sehingga tepung jagung dapat dijadikan sebagai bahan pengganti dan pensubstitusi tepung terigu dalam pembuatan produk,seperti biskuit.

Biskuit merupakan makanan yang cukup popular dikalangan masyarakat. Biskuit merupakan makanan praktis karena dapat dimakan kapan saja. Berbagai jenis biskuit telah dikembangkan untuk menghasilkan biskuit yang tidak hanya enak, tetapi juga bermanfaat bagi kesehatan. Dengan menambahkan bahan pangan tertentu seperti tepung jagung dalam pembuatan biskuit, dapat dihasilkan biskuit dengan nilai tambah yang baik untuk kesehatan. Namun semakin banyak porsi tepung jagung yang ditambahkan, mutu biskuit semakin rendah.

Lara dkk (2010) melaporkan bahwa pembuatan biskuit jagung memiliki kendala dari segi tekstur yang kurang baik, yaitu tekstur berpasir. Hasil yang sama telah dilaporkan oleh Cynthia dkk (2009), dengan memberikan solusi penambahan volume air dengan meningkatnya proporsi tepung jagung. Namun belum ada acuan yang pasti berapa volume air yang diperlukan setiap peningkatan porsi tepung jagung. Hal ini sesuai dengan pernyataan Rauf dan Sarbini (2015) bahwa penggunan campuran tepung yang berbeda pada berbagai perbandingan membutuhkan air 
yang berbeda-beda untuk mendapatkan produk dengan mutu yang baik.

Rauf dan Sarbini

menyatakan bahwa daya serap air dapat dijadikan acuan untuk menentukan volume air dari berbagai campuran tepung, termasuk campuran tepung jagung dan tepung terigu dalam pembuatan biskuit. Acuan daya serap air dalam penentuan volume air tersebut dinamakan volume air proporsional. Tujuan dari penelitian ini adalah untuk mengukur tingkat kekerasan dan daya terima biskuit dari campuran tepung jagung tepung terigu dan volume air yang proporsional.

\section{METODE PENELITIAN}

\section{Bahan}

Bahan utama yang digunakan dalam penelitian ini adalah tepung terigu, jagung varietas hibrida, baking powder, air, gula, telur, vanili, dan margarin. Jagung diperoleh dari pasar tradisional di Surakarta, sedangkan tepung terigu (soft flour), baking powder, air, gula, telur, vanili, dan margarin diperoleh dari supermarket di Surakarta.

\begin{abstract}
Alat
Peralatan yang digunakan terbagi atas dua kelompok, yaitu alat pengolahan dan alat analisis. Alat untuk pengolahan antara lain grinder, pengayak, oven, dan mixer adonan. Alat untuk uji kekerasan dengan menggunakanBrookfield CT3 texture analyzer.
\end{abstract}

\section{Pembuatan Tepung Jagung}

Prosedur pembuatan tepung jagung mengikuti laporan Richana dkk. (2007), yaitu penyortiran, penyosohan, penggilingan dan pengayakan dengan menggunaan ayakan 80 mesh.

\section{Pengukuran Daya Serap Air}

Dimbang tabung sentrifuge yang telah dikeringkan ( $\mathrm{Bt}$ ), timbang \pm 1 gram bahan dalam tabung sentrifuge (Bsampel), lalu ditambahkan $10 \mathrm{ml}$ aquades. Divortex selama 2 menit atau hingga tercampur, kemudian dilakukan sentrifuge selama 25 menit $300 \mathrm{rpm}$.Supernatant dipisahkan, lalu timbang tabung sentrifuge (Bpasta) (Valdez-Niebla dkk. 1993). Presentase daya serap air dihitung dengan menggunakan rumus:

$\%$ daya serap air $=\frac{\text { Bpasta }}{\text { btepung }} \times 100 \%$

\section{Penentuan Volume Air}

Penentuan volume air dilakukan dalam dua tahap. Tahap pertama, adonan dari campuran tepung jagung dan tepung terigu (40:60) dibuat produk biskuit dengan dua variasi volume air, yaitu $50 \mathrm{ml}$ dan $60 \mathrm{ml}$. Kedua produk tersebut kemudian dilakukan pengujian daya terima terhadap panelis untuk menentukan produk biskuit yang paling disukai.

Volume air yang terpilih untuk membuat adonan biskuit dari campuran tepung jagung dan tepung terigu, dijadikan sebagai acuan untuk tahap kedua. Pada tahap kedua dihitung volume air untuk setiap perlakuan variasi campuran tepung jagung dan tepung terigu, yang didasarkan pada daa serap airnya, sesuai laporan Rauf dan Sarbini (2015).

\section{Pembuatan Biskuit}

Pembuatan biskuit mengikuti prosedur Oluwamukomi dkk. (2011) dengan sedikit modifikasi. Bahan-bahan pembuatan adonan yaitu gula $(85,70 \mathrm{~g})$ direbus selama 20 menit kemudian didinginkan, setelah dingin dicampur dengan telur (35 g), margarin (71,40 g), baking powder $(2,30 \mathrm{~g})$ dan vanili $(3 \mathrm{~g})$ dengan menggunakan mixer hingga mengembang. Selanjutnya campuran tepung jagung dan tepung terigu (200 g) dimasukkan dan dimixer hingga kalis, 
setelah itu adonan dicetak dan dipanggang dengan suhu $180^{\circ} \mathrm{C}$ selama 15-20 menit.

\section{Uji Kekerasan}

Pengujian kekerasan mengikuti prosedur Choy $\mathrm{dkk}(2010)$ dengan sedikit modifikasi. Dilakukan pengaturan Pre-test speed : $1,5 \mathrm{~mm} / \mathrm{s}$, Test speed : $2,0 \mathrm{~mm} / \mathrm{s}$, Post-test speed : 10,0 mm/s, Distance : 5 $\mathrm{mm}$, Trigger force : auto $-25 \mathrm{~g}$, Tare mode: auto, data acquisition rate : 400 pps. Setelah itu biskuit diukur ketebalan dan diameternya kemudian diletakkan pada meja sampel. Alat dijalankan, probe akan bergerak menyentuh sampel hingga patah. Komputer akan memproses data hasil pergerakan alat dan perubahan yang terjadi dalam bentuk grafik (force vs time).

\section{Uji Daya Terima Biskuit Jagung}

Variasi daya terima yang diuji yaitu warna, aroma, rasa, tekstur dan keseluruhan. Pengujian didasarkan pada lima skala hedonik $1-5$, yaitu $1=$ sangat tidak suka, $2=$ tidak suka, $3=$ agak suka, $4=$ suka, $5=$ sangat suka. Pengujian dilakukan oleh 30 orang panelis mahasiswa Program Studi Ilmu Gizi Fakultas Ilmu Kesehatan, Universitas Muhammadiyah Surakarta.

\section{Rancangan Penelitian dan Analisis Data}

Penelitian ini menggunakan rancangan acak lengkap. Penentuan volume air melalui proses seleksi dari dua variasi volume air, yaitu $50 \mathrm{ml}$ dan $60 \mathrm{ml}$. Selanjutnya perlakuan variasi campuran tepung jagung dan tepung terigu yaitu 40:60, 60:40, 80:20 dan 100:0. Data dianalisis menggunakan ANOVA satu arah. Perbedaan hasil dianalisis menggunakan uji Duncan pada taraf 5\%.

\section{HASIL DAN PEMBAHASAN}

\section{A. Daya Serap Air}

Hasil pengujian daya serap air menunjukkan bahwa tepung jagung memberikan daya serap air yang lebih tinggi (Gambar 1).

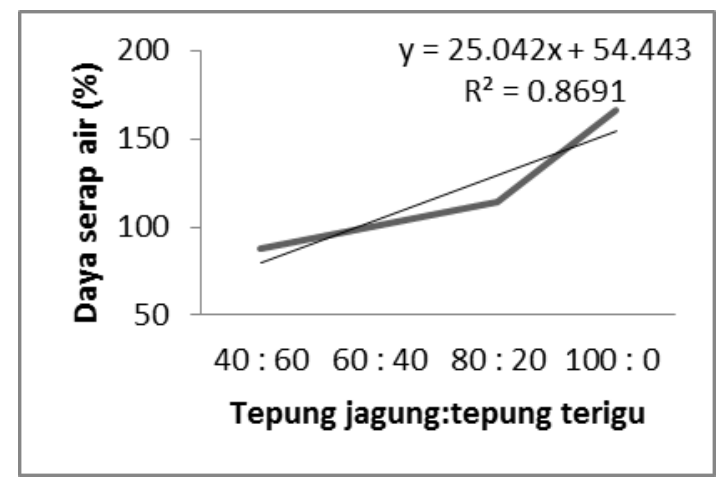

Gambar 1. Daya serap air campuran tepung jagung dan tepung terigu

Daya serap air yang ditunjukkan pada Gambar 1, memberikan kecenderungan yang linier, dengan nilai $\mathrm{R}^{2}=0.869$, artinya bahwa sebanyak $86,9 \%$ dari total daya serap air dipengaruhi oleh rasio campuran tepung jagung dan tepung terigu.Campuran tepung dengan porsi tepung jagung lebih banyak, menunjukkan daya serap air lebih tinggi di bandingkan dengan campuran tepung terigu yang lebih banyak.

Daya serap air dipengaruhi oleh keberadaan serat, protein, sertarasio amilosa dan amilopektin (Kusnandar, 2011).Amilosa memiliki molekul yang lebih kecil dibandingkan dengan amilopektin.Amilosa lebih mudah menjadi komponen yang larut air dibandingkan amilopektin pada saat dipanaskan (Rauf, 2015). Sajilata dkk. (2006) menyatakan bahwa struktur amorphous yang tinggi dari amilosa menyebabkan granula semakin mudah larut karena ikatan antar molekul pada bagian amorf tidak begitu kuat.

\section{B. Volume Air}

Air sangat menentukan konsistensi dan karakteristik reologi adonan, yang 
sangat menentukan sifat adonan selama proses dan akhirnya menentukan mutu produk yang dihasilkan (Koswara, 2009). Cynthia dkk. (2009) melaporkan bahwa penambahan air yang berbeda-beda pada pembuatan biskuit jagung berpengaruh terhadap adonan, tekstur dan rasa pada biskuit.

Pengujian daya terima terhadap biskuit dari campuran tepung jagung dan tepung terigu $(40: 60)$ dapat dilihat pada Gambar 2.

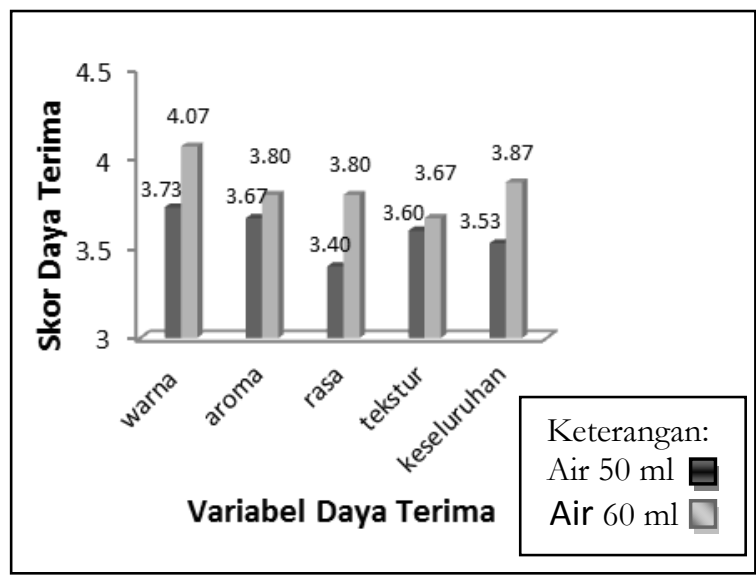

Gambar 2: Uji daya terima biskuit yang dibuat menggunakan volume air berbeda

Berdasarkan Gambar 2, menunjukkan bahwa penggunaan air sebanyak $60 \mathrm{ml}$ dalam pembuatan biskuit menunjukkan tingkat kekerasan yang lebih tinggi untuk semua variabel, dibanding volume $50 \mathrm{ml}$.

Pembuatan adonan biskuit dengan volume air yang berbeda dengan variasi campuran tepung jagung dan tepung terigu yang sama, menunjukkan bahwa adonan dengan penambahan air $50 \mathrm{ml}$ diperoleh adonan yang kalis dan mudah dicetak. Sedangkan adonan biskuit dengan pemanbahan air $60 \mathrm{ml}$, adonan lembek namun masih dapat dicetak.

Teknik kedua dalam penentuan jumlah air didasarkan pada daya serap air dari campuran tepung.Makin tinggi daya serap air campuran tepung, semakin banyak volume air yang diperlukan untuk membentuk adonan yang baik.Persamaan regresi linear dari daya serap air sampel campuran tepung dapat digunakan untuk menentukan volume air dalam pembuatan adonan biskuit sesuai dengan porsi campuran tepung.

C.

\section{Kekerasan Biskuit}

\section{Tingkat}

Kekerasan (hardness) merupakan indikator penting dalam menganalisis tekstur makanan terutama dalam produkproduk baked seperti roti dan biskuit (Wenzhoa dkk., 2013). Menurut Andarwulan dkk. (2011) kekerasan adalah sifat produk pangan yang menunjukkan daya tahan untuk pecah akibat gaya tekan yang diberikan. Tingkat kekerasan biskuit dapat dilihat pada Gambar 3.

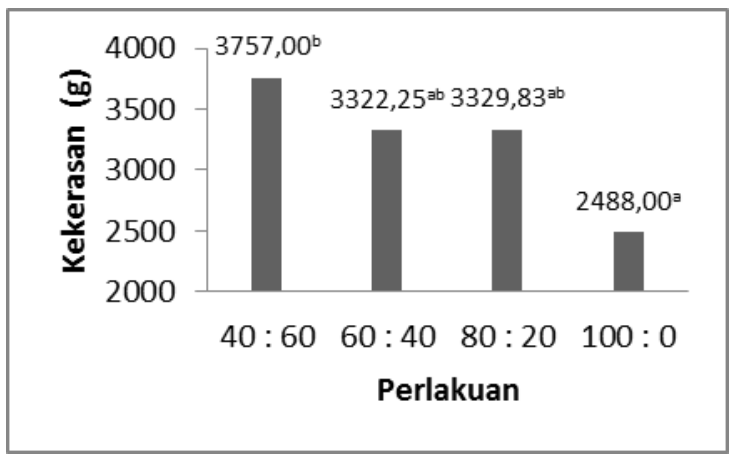

Gambar 3: Tingkat kekerasan biskuit campuran tepung jagung dan tepung terigu dengan volume air yang proporsional

Secara statistik, hasil peneitian menunjukkan ada pengaruh variasi campuran tepung jagung dan tepung terigu terhadap kekerasan biskuit, dengan nilai $p=0,04(<0,05)$. Makin tinggi porsi penambahan tepung jagung, kekerasan biskuit semakin rendah, artinya biskuit semakin mudah di patahkan. Hasil ini sejalan dengan penelitian (Yildiz dan Bulut, 2015) yang melaporkan bahwa kekerasankue semakin menurun seiring dengan penambahan air dan tepung kentang ke dalam formulasi 
adonan.Hendrasty(2013) melaporkan bahwa banyaknya air yang digunakan akanmemberikan kualitas produk yang diinginkan dan merupakan optimalisasi sebagai produk intermediate (adonan, batter dan pasta) yang akan menentukan sifat produk akhirnya.

\section{D.}

\section{Terima Biskuit}

\section{Warna}

Hasil uji statistik menunjukkan bahwa tidak terdapat pengaruh variasi campuran tepung jagung dantepung terigu dengan volume airyang proporsional terhadap warna biskuit, dengan nilai $p=$ 0,237 . Hal ini sesuai dengan penelitian Cynthia dkk. (2009) yang melaporkan bahwa tidak terdapat beda nyata terhadap warna biskuit dari campuran tepung jagung dan tepung terigu. Gambaran daya terima warna biskuit yang terbuat campuran tepung jagung dan tepung terigu dapat dilihat pada Gambar 4.

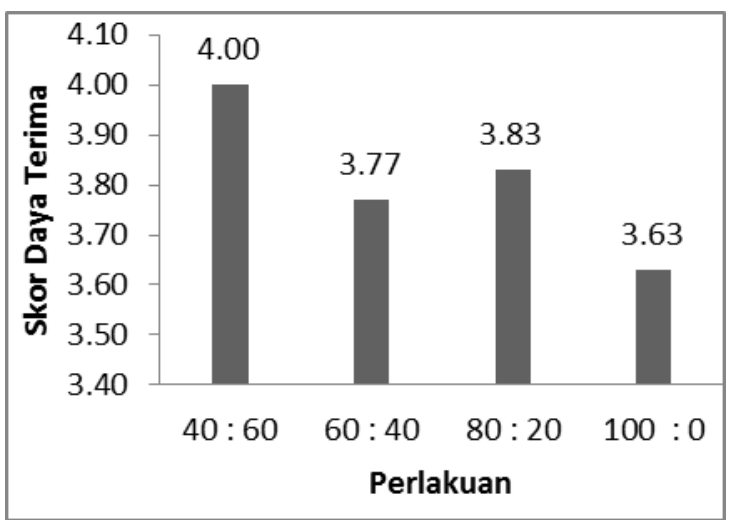

Gambar 4. Daya terima warna biskuit campuran tepung jagung dan tepung terigu dengan volume air yang proporsional

Gambar 4 menunjukkan bahwa skor daya terima warna berada pada kisaran antara 3,63-4,00, artinya masih berada pada rentang yang disukai oleh panelis. Warna biskuit berasal dari warna bahan baku yang digunakan (Cynthiadkk.,2009) dan terjadinya reaksi Maillard pada saat pemanggangan. Reaksi Maillard merupakan reaksi antara gula pereduksi dengan gugus amino primer yang menghasilkan polimer nitrogen berwarna coklat atau melodin, yang sering dikehendaki ataupun menjadi tanda terjadinya penurunan mutu produk (Suarni, 2009).

\section{Aroma}

Secara statistik hasil penelitian menunjukkan bahwa terdapat pengaruh variasi campuran tepung jagung dantepung terigu dengan volume air yang proporsional, dengan nilai $p=0,005$. Gambaran tingkat penerimaan aroma biskuit dari campuran tepung jagung dan tepung terigu dapat dilihat pada Gambar 5.

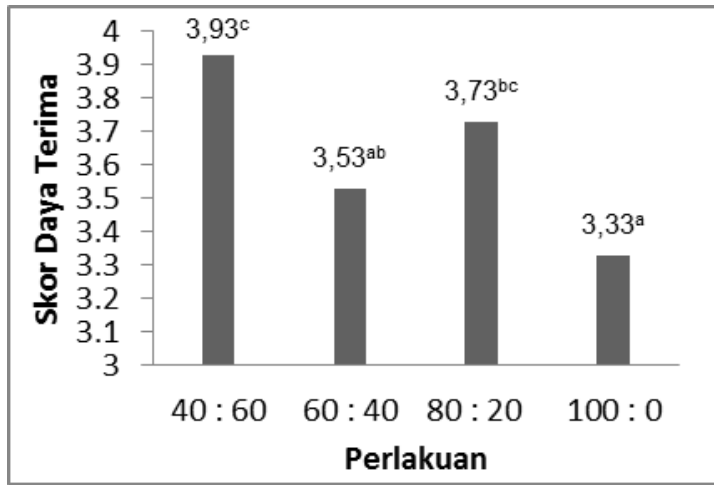

Gambar 5. Daya terima aroma biskuit campuran tepung jagung dan tepung terigu dengan volume air yang proporsional

Gambar 5 menunjukkan bahwa, skor daya terima biskuit tertinggi diberikan oleh variasi campuran tepung jagung dan tepung terigu dengan volume air yang proporsional dari perlakuan 40:60. Sedangkan daya terima terendah diberikan oleh variasi campuran tepung jagung, tepung terigu dan volume air dari perlakuan 100:0.

Hasil penelitian Suarni (2009) melaporkan bahwa persentas substitusi tepung jagung terhadap terigu akan 
mempengaruhi aroma produk. Penambahan tepung jagung hingga $80 \%$ masih dapat dierimma oleh panelis sedangkan penggunaan tepung jagung $100 \%$ memberikan tingkat penerimaan yang rendah.

Aroma biskuit terbentuk selama proses pemanggangan. Selama pemanggangan senyawa-senyawa volatil menguap sehingga aroma bahan dasar sebagian besar hilang akibat pemasakan (Febrianto dkk., 2014). Selain itu Subandoro dkk (2013) menyatakan bahwa aroma biskuit dapat disebabkan oleh berbagai komponen bahan lain dalam adonan seperti margarin, gula dan bahan pengembang.

\section{Rasa}

Berdasarkan uji statistik menunjukkan bahwa terdapat pengaruh variasi campuran tepung jagung dantepung terigu dengan volume air yang proporsional, dengan nilai $p=0,005$. Gambaran daya terima aroma biskuit dari campuran tepung jagung dan tepung terigu dapat dilihat pada Gambar 6.

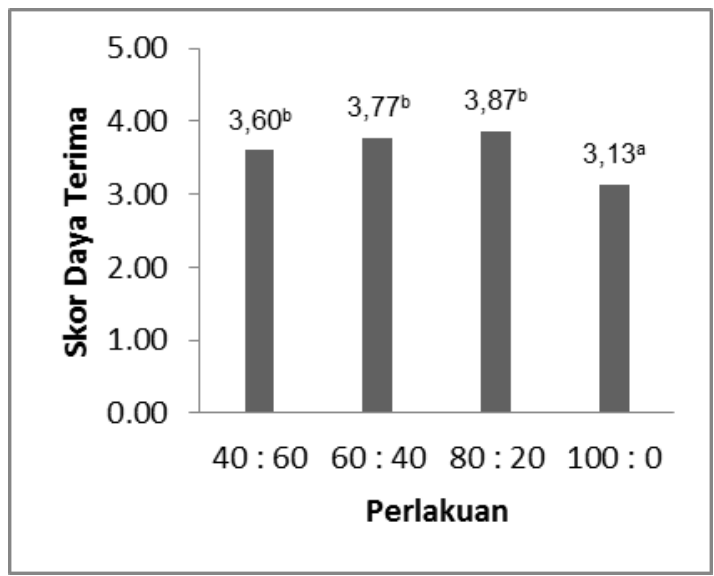

Gambar 6. Daya terima rasa biskuit campuran tepung jagung dan tepung terigu dengan volume air yang proporsional

Daya terima biskuit dari campuran tepung jagung dan tepung terigudengan volume air yang proporsional dari perlakuan 40:60, 60:40 dan 80:20 menunjukkan bahwa tidak ada perbedaan yang nyata.Perbedaan hanya tampak pada perlakuan 100:0 yang menunjukkan skor kesukaan yang paling rendah.

Rendahnya daya terima pada perlakuan 100:0, sesuai dengan pernyataan Hirda dkk.(2014) bahwa semakin tinggi perbandingan tepung jagung maka nilai organoleptik rasa dari cookies juga semakin menurun. Hal yang sama juga dilaporkan oleh Murtiningsih (2013) bahwa rasa biskuit semakin menurun seiring dengan meningkatnya proporsi tepung jagung.

Rasa pada biskuit dapat dipengaruhi oleh bahan lain yang ditambahkan seperti margarin yang mampu memperbaiki cita rasa pada biskuit, selain itu adanya protein yang terkandung pada tepung jagung dan tepung terigu dapat menimbulkan reaksi Maillardpada suatu bahan pangan (Murtiningsih, 2013).

\section{Tekstur}

Hasil analisis menunjukkan bahwa tidak terdapat pengaruh variasi campuran tepung jagung dantepung terigu dengan volume air yang proporsional, dengan nilai $p=0,093$. Gambaran daya terima tekstur biskuit yang terbuat dari campuran tepung jagung dan tepung terigu dapat dilihat pada Gambar 7.

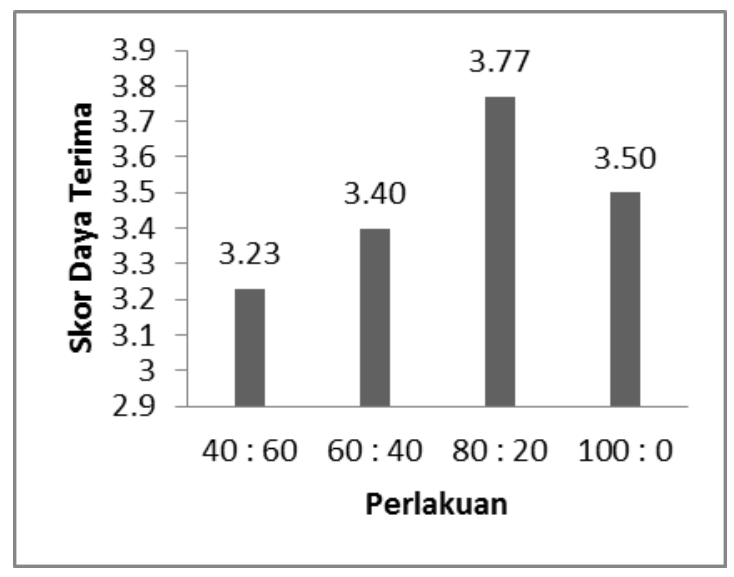

Gambar 7. Daya terima tekstur biskuit campuran tepung jagung dan tepung 
terigu dengan volume air yang proporsional

Gambar 7 menunjukkan bahwa skor daya terima warna berada pada kisaran antara 3,23-3,77, artinya masih berada pada rentang yang masih disukai oleh panelis Dalam hal ini, tekstur biskuit dipengaruhi oleh semua bahan baku yang digunakan. Menurut Azni (2013), skor daya terima tekstur yang tidak signifikan pada setiap perlakuan karena seluruh bahan pembuatan biskuit ubi ungu dapat mempengaruhi tekstur. Misalnya lemak yang dapat merenyahkan dan kuning telur yang melembutkan biskuit jagung. Tekstur pada biskuit juga di pengaruhi oleh jumlah tepung jagung yang berbeda-beda serta juga dipengaruhi oleh penambahan air yang berbeda-beda.

Hasil penelitian Hirda dkk. (2014) melaporkan bahwa semakin tinggi penambahan tepung jagung maka tekstur yang dihasilkan semakin tidak renyah. Tepung terigu mempunyai kadar amilosa yang lebih tinggi dibandingkan dengan tepung jagung. Kadar amilosa dapat mempengaruhi tekstur yang diperoleh oleh suatu bahan pangan. Menurut Harzau dan Estiasih (2013) perbandingan antara amilosa dan amilopektin berpengaruh terhadap tekstur cookies. Amilopektin dalam bahan pangan menghasilkan kemampuan perekat yang menyebabkan struktur cookies menjadi lebih kokoh. Selain itu, kadar air yang juga berpengaruh terhadap tekstur suatu produk pangan.

Apriliani (2010) menyatakan bahwa keberadaan air dalam suatu produk pangan akan mempengaruhi lunak atau kerasnya suatu produk. Selain itu, Cynthia dkk. (2009) juga menambahkan bahwa, penggunaan air yang berbeda-beda juga akan mempengaruhi tekstur dari biskuit jagung. penggunaan air meningkat seiring penambahan tepung jagung dalam adonan.
Air mengikat protein sehingga membentuk gluten. Walaupun kadar protein sebagian besar kombinasi tepung jagung tergolong sedang, tetapi jagung tidak memiliki protein gluten yang merupakan protein utama pada terigu. Gluten bermanfaat untuk mengikat dan membuat adonan menjadi elastis sehingga mudah dibentuk dan tekstur produk yang dihasilkan menjadi renyah (Anshari, 2010).Lara dkk.(2010) melaporkan bahwa tidak adanya gluten dalam tepung jagung mempengaruhi kestabilan gelembung gas yang seharusnya dilakukan oleh gluten dan akhirnya diperantarai oleh lemak.Hal ini menyebabkan tekstur biskuit jagung yang dihasilkan kurang bagus dengan permukaan yang kasar dan pori-pori yang sangat banyak serta hancur dibeberapa bagian.

\section{Keseluruhan}

Kesukaan keseluruhan atau penerimaan secara umum merupakan penilaian panelis terhadap suatu produk secara keseluruhan berdasarkan warna, aroma, rasa dan tekstur.Hasil analisis menunjukkan bahwa terdapat pengaruh variasi campuran tepung jagung dan tepung terigu dengan volume air yang proorsional, dengan nilai $p=0,003$. Gambaran tingkat ppenerimaan keseluruhan biskuit yang dibuat dari campuran tepung jagung dan tepung terigu dapat dilihat pada Gambar 8 .

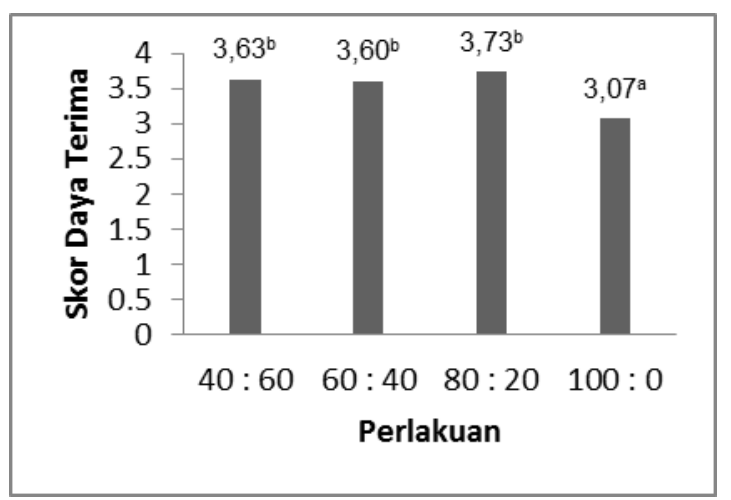


Gambar 8. Daya terima keseluruhan biskuit campuran tepung jagung dan tepung terigu dengan volume air yang proporsional

Berdasarkan Gambar 8, Tingkat penerimaan biskuit dari campuran tepung jagung dan tepung terigu dengan volume yang proporsional dari perlakuan 40:60, 60:40 dan 80:20 menunjukkan bahwa tidak ada perbedaan yang nyata. Perbedaan hanya tampak pada perlakuan 100:0 yang menunjukkan skor kesukaan yang paling rendah.

Penilaian panelis terhadap kesukaan keseluruhan dipengaruhi oleh penilaian terhadap warna, aroma, rasa, dan tekstur biskuit dengan variasi campuran tepung jagung, tepung terigu dan volume air. Berdasarkan skor daya terima keseluruhan, biskuit dengan campuran tepung jagung, tepung terigu dan volume airdari perlakuan 80:20 merupakan produk yang paling disukai oleh panelis, dimana sudah tidak ada tekstur berpasir ada akhir rasa. Berdasarkan penelitian Cynthia dkk. (2009) bahwa penerimaan keseluruhan biskuit jagung yang paling disukai oleh panelis adalah variasi campuran tepung jagung, tepung terigu 80:20.

\section{KESIMPULAN}

Daya serap air campuran tepung jagung dan tepung terigu menunjukkan bahwa semakin tinggi porsi tepung jagung, maka semakin tinggi daya serap air dari campuran tepung, yang membentuk garis linier dengan persamaan $\mathrm{y}=25,04 \mathrm{x}+54,44$ dan nilai $\mathrm{R}^{2}=0,689$. Hasil uji kekerasan menunjukkan terdapat pengaruh variasi campuran tepung jagung, tepung terigu dan volume air, dengan nila $p=0,042$. Sedangkan hasil analisis daya terima tidak terdapat pengaruh variasi campuran tepung jagung dan tepung terigu terhadap daya terima pada biskuit berdasarkan warna dan tekstur, tetapi ada pengaruh campuran tepung jagung dan tepung terigu terhadap daya terima pada biskuit berdasarkan aroma, rasa, dan keseluruhan. Biskuit dengan campuran tepung 80:20 memiliki tingkat kesukaan yang tertinggi.

\section{DAFTAR PUSTAKA}

Andarwulan N, Kusnandar, F dan Herawati, D., 2011, Analisa Pangan, PT. Dian Rakyat, Jakarta.

Anshari H., 2010, Pemanfaatan Biji Cempedak Sebagai Alternatif Pengganti Tepung Terigu, PKM, Universitas Negeri Malang, Malang.

APTINDO., 2014, Data Impor Gandum Indonesia, Jakarta.

AprilianiM. W., 2010, Pengaruh penggunaan tepung tapioka dan carboxymethyl cellulose (CMC) pada pembuatan keju mozzarella terhadap kualitas fisik dan organoleptik. Fakultas Peternakan, Universitas Brawijaya, Malang.

Azni M. E., 2013, Evaluasi Mutu Kukis Berbahan Tepung Ubi Jalar Ungu (Ipomoea batatas L), Tepung Tempe dan Tepung Udang Rebon (Aceteserythraeus). Fakultas Pertanian Universitas Riau, Pekanbaru.

Brand-Miller., 2008, Low -glycemic index diets in the management of diabetes: A meta-analysis ofrandomized controlled trials. Diabetes Care, 26, 2261-2267. 
International tabels of glicemic index, American Journalof Clinical Nutrition. 62: 871-893.

Choy, Ai-ling., J.G. Hughes, D.M. Small., 2010, The Effect of Microbial Transglutaminase, Sodium Steroyl Lactylate and Water on The Quality of Instant Fried Noodles, Journal of Food Chemistry 122:957-964.

Cynthia Gracia C.L, Sugiyono, Bambang Haryanto., 2009, Kajian Formulasi Biskuit Jagung Dalam Rangka Substitusi Tepung Terigu, Jurnal Teknologi dan Industri Pangan, Vol. xx no. 1.

Febrianto N. A., 2014, Kajian Karakteristik Fisikokimia Dan Sensoris Tortila Corn Chips Dengan Variai Larutan Alkali Pada Proses Nikstamalisasi Jagung, Jurusan Ilmu dan Teknologi Pangan, Fakultas Pertanian, Universitas Sebelas Maret Surakarta.

Harzau dan Estiasih., 2013, Karakteristik cookies umbi inferior uwi putih (kajian proporsi tepung uwi : patu jagung dan penambahan margarin), Jurnal Pangan dan Agroindustri 1(1) : 138-147.

Hendrasty., 2013, Bahan Produk Bakery, Graha Ilmu, Yogyakarta.

Hirda M, Linda, M dan Zulkifli L., 2014, Pengaruh Metode Pembuatan Tepung Jagung Dan Perbandingan Tepung Jagung Dan Tepung Beras Terhadap Mutu Cookies. Program Studi Ilmu danTeknologi Pangan Fakultas Pertanian USU: Medan.

Koswara., 2009, Teknologi Pengolahan Roti. (Teori dan Praktek), eBook Pangan.

Kusnandar, F., 2011, Kimia Pangan Komponen Makro, Dian Rakyat, Jakarta.

Lara E, Cortes P, Briones V, Perez M., 2010, Structural and Physical Modification of Corn Biscuit During Baking Process, LWT-Food Sci Technol 1-34.

Murtiningsih., 2013, Peran Pektin dan Sukrosa Pada Selai Ubi Jalar Ungu, UPN Jawa Timur, Surabaya.

Nuraini., 2013, Teknolohi Fermentasi Pada Tepung Jagung, Graha Ilmu, Yogyakarta.

Oluwamukomi, M. O.,I. B. Oluwalana, and O. F. Akinbowale., 2011, Physicochemical and sensory properties of wheat-cassava composite biscuit enriched with soy flour, African Journal of Food Science Vol. 5 (2) pp. 50 - 56.

USDA (United States Departement of Agriculture), 2013, Nutrition facts label for sponge cake (comersially prepared).

Rauf R., Sarbini D., Rahmatika N. A., 2015, Penentuan Jumlah Air yang Berbeda Terhadap Sifat Viskoelastisitas Adonan yang Terbuat dari Campuran Tepung 
Terigu dan Tepung Singkong, Laporan Penelitian Reguler Kompetitif, LPPM UMS, Surakarta.

Richana N., Ratnaningsih A.B., Arif, and Hayuningtyas M., 2012, Characterization of varieties of maize with a low glycemic index to support food security. International Maize Conference in Gorontalo.

Richana, N dan Suarni., 2007, Teknologi Pengolahan Jagung, Balai Besar Penelitian dan Pengembangan Pascapanen, Bogor.

Sajilata M.G., R.S. Singhal, dan Kulkarni P.R., 2006, Resistant starch a review, CRFSFS Vol 5.

Suarni., 2009, Prospek Pemanfaatan Tepung Jagung untuk Kue Kering (Cookies), Jurnal Penelitian dan Pengembangan Pertanian, Badan Pengembangan Pertanian, Bogor.

Subandoro R.H., Basito dan Atmaka W., 2013, Pemanfaatan Tepung Millet Kuning dan Tepung Ubi Jalar Kuning Sebagai Subtitusi Tepung Terigu dalam Pembuatan Cookies Terhadap Karakteristik Organoleptik dan Fisikokimia, Jurnal Teknosains Pangan Vol 2 No 4.

Yildiz O dan Bulut B., 2015, Optimization of Gluten-Free Tulumba Dessert Formulation Including Corn Flour: Response Surface Methodology Approach, Department of Food Engineering, Faculty of Engineering, Igdir University, 76000-Igdir. Turkey, Vol. 67, No. 1.

valdez-Niebla, J. A., Parades-Lopez O., Vargas-Lopez, J. M. Dan Hernandez-Lopez, D., 1993, Moisture Sorption Isotherms and other physicochemical properties of nixtamalized amaranth flour, food chemistry, 46: 19-23.

Wenzhao L., Guangpeng L., BaolingS. Xianglei T., Xu, S., 2013, Effect of Sodium Stearoyl and the Microstruture of Dough. Advance Journal of Food Scence and Technology 5(6):682-687. 